\title{
Patrząc na Wschód: Unia Europejska wobec niestabilnego wschodniego sąsiedztwa
}

\section{Wstęp}

Patrząc na mapę Europy Środkowo-Wschodniej, możemy powiedzieć, że istotne geopolityczne zmiany na tym obszarze nastapiły na przełomie lat 80. i 90. XX wieku. Doszło wówczas do rekonfiguracji porządku międzynarodowego, w tym na kontynencie europejskim. Wraz z rozpadem Związku Radzieckiego pojawiły się na mapie nowe państwa wyzwolone z okowów radzieckich oraz państwa wyzwolone z zależności satelickiej względem ZSRR. Następnym niezwykle ważnym wydarzeniem była integracja części państw Europy Środkowej (Polska, Czechy, Węgry) z NATO (1999 rok) oraz z Unią Europejską (2004 rok). W związku z tym w Europie Środkowo-Wschodniej powstała całkowicie nowa - w porównaniu $\mathrm{z}$ realiami z początku lat 90. XX wieku - sytuacja geopolityczna. Rozszerzenie UE o państwa Europy Środkowej (w szczególności o Polskę) przyczyniło się do zmiany w podejściu Wspólnoty do obszaru poradzieckiego. Do momentu rozszerzenia UE w kierunku wschodnim Wspólnota nie widziała potrzeby zacieśniania stosunków z państwami poradzieckimi, gdyż dominowała zasada „Russia first”. Po 2004 roku obserwujemy powolną zmianę podejścia UE do wschodniego sąsiedztwa. Do kolejnej geopolitycznej zmiany na obszarze Europy Wschodniej i Kaukazu Południowego doszło w wyniku wojny pięciodniowej między Rosją i Gruzją (sierpień 2008 roku) (Stępniewski, 2011, s. 209-212) oraz aneksji Krymu przez Rosję. Wyzwaniem - można powiedzieć, że o znaczeniu fundamentalnym - jest trwający konflikt zbrojny na Donbasie między Rosją i Ukrainą (od 2014 roku) (szerokie omówienie uwarunkowań, przebiegu i znaczenia konfliktu na Ukrainie m.in. w: „Rocznik Instytutu Europy Środkowo-Wschodniej”, 2014; Harasimowicz, 2016, s. 29-34; Delcour, Wolczuk, 2015, s. 459-478; Haukkala, 2015, s. 25-40; Judah, 2015; Larrabee, Wilson, Gordon 2015; Shekhovtsov, Umland, 2014; Wilson, 2014; Barburska, Milczarek, 2014).

Niniejszy artykuł - w sposób bardzo skrótowy - analizuje politykę Unii Europejskiej wobec wschodnich sąsiadów. W pierwszej kolejności ukazana zostanie sytuacja UE (kryzysy, z jakimi boryka się Wspólnota), a następnie zaprezentowana zostanie sytuacja państw wschodniego sąsiedztwa (przez pryzmat polityki Partnerstwa Wschodniego), z położeniem nacisku na tzw. kryzys ukraiński. Ukazane zostaną również działania Polski i innych państw Grupy Wyszehradzkiej wobec wschodniego sąsiedztwa. Kryzys ukraiński, de facto konflikt zbrojny Rosji z Ukrainą, powoduje, że zmianie uległa nie tylko sytuacja geopolityczna Europy Wschodniej, ale również warunki, w jakich realizowana jest polityka wschodnia Unii Europejskiej. Inaczej mówiąc, agresja 
Rosji na Ukrainę spowodowała, że UE znalazła się w bardzo trudnej sytuacji i zmuszona została do zmiany swej polityki względem Rosji.

\section{Unia Europejska targana kryzysami wewnętrznymi i zewnętrznymi}

Wewnątrz Unii Europejskiej pojawia się wiele problemów i kryzysów, z których zwłaszcza jeden - „Brexit” - stanowi olbrzymie wyzwanie dla projektu europejskiego. Po raz pierwszy w historii Unii Europejskiej państwo opuści Wspólnotę. Tym samym zmienia się logika funkcjonowania UE, co może mieć negatywne skutki dla państw aspirujących do członkostwa w niej. Ponadto w ramach Unii Europejskiej występują także inne kryzysy, które częściowo wynikają z problemów z dostosowaniem systemów politycznych państw europejskich do zmieniającej się rzeczywistości, na co dość często wpływ mają również zewnętrzne wstrząsy. Zdaniem Jana Zielonki, w ramach UE mamy do czynienia nie tylko z kryzysem demokracji, ale również z kryzysem kapitalizmu, kryzysem integracji europejskiej (kryzys przywództwa i wizji), kryzysem uchodźców, a także z kryzysem moralnym (o czym wspomina w swych wystąpieniach również papież Franciszek) (Żakowski, 2016, s. 24). Do powyższego katalogu kryzysów można dodać jeszcze kryzys systemu bezpieczeństwa (Góralczyk, 2014, s. 233 i nast.). Dodatkowo w otoczeniu międzynarodowym UE sytuacja jest obecnie bardzo trudna, co też nie pozostaje bez wpływu na kształt jej polityki wobec sąsiadów. Należy wspomnieć o wojnie w Syrii, działaniach w Libii, kwestii olbrzymiej liczby migrantów w regionie śródziemnomorskim, problemie tzw. Państwa Islamskiego, neoimperialnej polityce Rosji (aneksja Krymu i wspieranie przez nią separatystów w południowej i wschodniej części Ukrainy) etc. (szerzej na ten temat w: Fiszer, 2014, s. 33-52; Kuźniar, 2016; Góralczyk, 2014b; Stępniewski, 2015, s. 11-25).

\section{Wpływ Brexitu na wschodni wymiar Unii Europejskiej}

Poprzedni premier Wielkiej Brytanii David Cameron wielokrotnie w czasie swoich wystąpień publicznych mówił o konieczności przeprowadzenia referendum w sprawie członkostwa UK w Unii Europejskiej. Słowa te urzeczywistniły się - referendum zostało rozpisane. W dniu 23 czerwca 2016 roku społeczeństwo Wielkiej Brytanii opowiedziało się za opuszczeniem Unii Europejskiej (wynik referendum był następujący: $51,9 \%$ za opuszczeniem UE; $48,1 \%$ za pozostaniem w UE) (szerzej na temat krajobrazu politycznego po Brexicie w: Kaczorowska, 2016, s. 39-61). W związku z tym zaistniała konieczność ułożenia nowych stosunków UE-Wielka Brytania. Do wyboru jest wiele scenariuszy rozwoju sytuacji. Dwa wydają się dość prawdopodobne: pierwszy - handel preferencyjny w stosunkach dwustronnych, drugi - utrzymanie wspólnego rynku. Ostateczna forma stosunków będzie zależała od negocjacji dwustronnych oraz od decyzji głównych państw UE, jak Niemcy, Francja, Włochy, Hiszpania czy też Polska. Co ciekawe, trwające negocjacje, a raczej chaos w negocjacjach między Wielką Brytanią a UE powoduje, że obecne stosunki między UE a Ukrainą stają się do pewnego stopnia modelem, który potencjalnie może zostać zastosowany w relacjach UE 
z post-Brexitową Wielką Brytanią. Słusznie zauważa Timothy Garton Ash, że „,choć trudno w to uwierzyć - Wielka Brytania przygląda się m.in. stosunkom unijno-ukraińskim jako modelowemu rozwiązaniu" (Ash, 2017).

Członkostwo Wielkiej Brytanii w Unii od 1973 roku miało wpływ na kształt nie tylko polityki wewnętrznej UE, ale również polityki zagranicznej, w tym polityki wobec Europy Wschodniej i Rosji. Wielka Brytania kładła nacisk na politykę rozszerzenia i dość często sceptycznie odnosiła się do polityki rosyjskiej wobec państw Europy Wschodniej. Brexit oznacza, że UE i jej polityka zagraniczna ulegną zmianom. Brak państwa, które miało potencjał i siłę oddziaływania na instytucje UE, może również wpłynąć na relacje Unii z państwami wschodnimi. Dodatkowo Wielka Brytania dość często podzielała stanowisko Polski dotyczące państw PW oraz wspierała inicjatywy i projekty skierowane do tej części Europy. Można stwierdzić, że Brexit będzie miał negatywne skutki nie tylko dla Wielkiej Brytanii, ale również dla Wspólnoty. Istotne jest również to, że będzie miał niekorzystny wpływ na kształt i kierunki współpracy UE z państwami Europy Wschodniej.

\section{Państwa Partnerstwa Wschodniego w optyce Unii Europejskiej}

Analizując sytuację państw Partnerstwa Wschodniego (szersze ujęcie sytuacji państw wschodnich objętych Europejską Polityką Sąsiedztwa i projektem Partnerstwa Wschodniego w: Kostanyan, 2017; Bouris, Schumacher, 2016; Thompson, 2015; Lannon, 2015; Rieker, 2014) Unii Europejskiej w warunkach trwającego na Ukrainie konfliktu zbrojnego (inaczej tzw. kryzys ukraiński) (szerzej nt. kryzysu ukraińskiego w: Youngs, 2017; Besier, Stokłosa, 2017; Korosteleva, 2016a; Natorski, 2016; Sakwa, 2016), należy zauważyć, że projekt ten poddawany jest wielkiej próbie w postaci tzw. kryzysu ukraińskiego.

Według przedstawiciela Europejskiej Służby Działań Zewnętrznych (EEAS) UE, Partnerstwo Wschodnie jest projektem dojrzałym (Wywiad 1, 2016). Pomimo że traci na dynamice i że obecnie realizowany jest w specyficznych warunkach, nie można zapominać o tym, że postanowienia ze szczytów w Wilnie i Rydze są pomyślnie implementowane. Platformy wielostronne działają, dochodzi do spotkań na różnych szczeblach. Być może spotkania te są mało widoczne, ale odbywają się i wpływają W mniejszym lub większym stopniu na sytuację państw PW.

Należy zaznaczyć, że najważniejszym problemem dla PW jest postrzeganie tego projektu w kategoriach geopolitycznych - myślenie o państwach PW w kontekście konieczności dokonania wyboru: albo z UE, albo z Rosją (słuchając wypowiedzi decydentów politycznych z UE, często można odnieść wrażenie, że państwa te nie mają innej opcji). Natomiast Polska i Szwecja, tworząc ten projekt, nie zakładały, że państwa nim objęte będą musiały dokonać takiego wyboru ${ }^{1}$. Wyboru, który dla tych państw jest niezwykle trudny i wiąże się z wieloma komplikacjami (w przypadku Ukrainy obecnie są to trudności o charakterze egzystencjalnym). Oczywiste jest, że z najskuteczniejszą

${ }^{1}$ Partnerstwo Wschodnie zostało zainaugurowane przez Unię Europejską w czasie szczytu w Pradze 7 maja 2009 roku. PW jest projektem UE skierowanym do sześciu państw wschodniego sąsiedztwa UE: Armenii, Azerbejdżanu, Białorusi, Gruzji, Mołdawii i Ukrainy. 
polityką mamy do czynienia wtedy, gdy towarzyszy ona perspektywie członkostwa w strukturach UE. Brak perspektywy takiego członkostwa powoduje, że UE nie ma instrumentów nacisku na te państwa (Wywiad 2, 2016). Ale nie należy również zapominać, że państwa PW nie są obecnie gotowe do integracji europejskiej (biorąc pod uwagę niemal wszystkie kryteria członkostwa). Warto wspomnieć, że według najnowszych rankingów antykorupcyjnych w 2005 roku Ukraina zajmowała 107. miejsce na świecie, a w 2015 roku spadła na pozycję 142. Ponadto nie wszystkie państwa objęte projektem PW deklarują zamiar integracji z UE. O ile Gruzja, Mołdawia i Ukraina wyrażają chęć integracji z UE oraz implementują AA/DCFTA, o tyle Armenia, Azerbejdżan i Białoruś nie wyrażają takiej chęci. Jednak w ostatnim czasie prowadzone są rozmowy z Armenią w sprawie możliwości podpisania DCFTA (w formie, która nie będzie kolidowała z członkostwem Armenii od 2014 roku w Unii Eurazjatyckiej, kierowanej przez Rosję). Jeśli rozmowy na temat podpisania umowy z Armenią powiodą się, wówczas będzie możliwość rozpoczęcia takich rozmów z Azerbejdżanem i Białorusią (Wywiad 1, 2016). Również społeczeństwa państw PW są podzielone, jeśli chodzi o perspektywę integracji z UE.

Biorąc pod uwagę sytuację wewnętrzną państw PW, najlepszym rozwiązaniem dla UE będzie położenie nacisku na pragmatyzm, elastyczność i poszukiwanie możliwości współpracy. Oczywiście polityka UE nadal powinna opierać się na zasadzie „more for more", która nie jest już stosowana w ramach EPS, ale logika tego działania nadal obowiązuje w ramach Europejskiej Polityki Sąsiedztwa (Popowski, 2016). UE powinna również wdrożyć zasadę „less for less” w odniesieniu do państw PW. Przykładami takiego pragmatycznego działania jest wspieranie reform w państwach PW. Od skuteczności reform zależy pomyślność transformacji tych państw. Jeśli nie uda się przeprowadzić reform, trudno będzie mówić o zacieśnianiu relacji między UE i państwami PW. Wyraźnie należy zaznaczyć, że UE nie może odrobić lekcji za państwa PW. One same muszą dążyć do zmian i przeprowadzić reformy. Dlatego też UE powinna zaangażować o wiele większe środki finansowe na reformowanie tych państw. Problemem jest oczywiście korupcja (przykładem może być Mołdawia, w której doszło w ostatnim czasie do defraudacji środków UE). Dnia 22 września 2016 roku Bank Światowy opublikował swoje najświeższe prognozy na temat ukraińskiej sytuacji gospodarczej. Zgodnie z danymi BŚ wzrost ekonomiczny na Ukrainie w pierwszej połowie 2016 roku wyniósł $0,8 \%$ (The World Bank, 2016). BŚ zauważa, że reformy są zbyt wolne, a słabość popytu zewnętrznego i konflikt z Rosją niszczą ożywienie gospodarcze na Ukrainie. Można powiedzieć, że teraz jest czas na działania UE w tym zakresie. Ukraina sama nie poradzi sobie ze skalą problemów i wojną z Rosją na Donbasie.

Kolejną kwestią jest liberalizacja ruchu wizowego. Mołdawia, Gruzja i w ostatnim czasie Ukraina zostały objęte ruchem bezwizowym. Ukraina spełniała wszystkie wymogi postawione jej przez UE już od dłuższego czasu, lecz decyzja w tej sprawie zapadła dopiero w połowie 2017 roku. W UE prowadzone były też prace nad mechanizmem bezpieczeństwa, czyli wprowadzeniem „mechanizmu zawieszenia” (ang. „a suspension mechanism”) na wypadek złamania przez państwa objęte tym mechanizmem zasad funkcjonowania ruchu bezwizowego (ang. ,visa-free travel in the EU”). Na niekorzyść Ukrainy świadczył fakt, że mechanizm ten UE przygotowywała na potrzeby potencjalnego ruchu bezwizowego z Turcją. Połączenie tych spraw opóźniało wdrożenie tego 
projektu dla Ukrainy i Gruzji. Ponadto nie należy zapominać, że Ukraina nie kontroluje całego swojego terytorium (Krym został zaanektowany przez Rosję, Donbas ogarnięty jest wojna). Z punktu widzenia skuteczności polityki UE jest niezwykle ważne, żeby społeczeństwa tych państw nie stały się zakładnikami sytuacji politycznej. Obywatele państw PW powinni mieć możliwość przyjazdu na terytorium UE. Tym bardziej że UE w odniesieniu do państw PW kładzie nacisk na kontakty międzyludzkie (ang. ,peopleto-people contacts"). Ponadto UE powinna jeszcze bardziej wspierać społeczeństwo obywatelskie w państwach PW, młodych polityków i liderów politycznych, którzy chcą zmian, wolne media, średnie i małe przedsiębiorstwa etc. Można postawić tezę, że wydaje się mało prawdopodobne, że systemy polityczne tych państw w najbliższej przyszłości nie ulegną zmianie, dlatego też UE powinna wspierać społeczeństwo obywatelskie i inicjatywy oddolne. To właśnie bunt społeczny przeciw reżimowi W. Janukowycza, który określamy mianem Euromajdanu (także „rewolucja godności”), na Ukrainie w lutym 2014 roku spowodował zmianę sytuacji politycznej tego państwa. Tak więc widać, że potencjał obywatelski Ukrainy - i w mniejszym stopniu innych państw PW - jest olbrzymi i decydenci państw członkowskich UE powinni o tym pamiętać.

\section{Neoimperialna polityka Federacji Rosyjskiej wobec Europy Wschodniej i Kaukazu Południowego}

Należy zaznaczyć, że państwa Partnerstwa Wschodniego nie funkcjonują w próżni, są zależne od uwarunkowań wewnętrznych oraz zewnętrznych. Spośród uwarunkowań zewnętrznych ważna jest postawa nie tylko UE, ale również Rosji. Dlatego też z punktu widzenia sytuacji państw PW istotne jest spojrzenie na cele Rosji (cele realistyczne, a nie deklarowane) wobec tych państw. Chodzi o rozpoznanie celów taktycznych, ale również celów strategicznych wobec państw PW, szerzej wobec państw poradzieckich. Można powiedzieć, że od wybuchu wojny Rosji z Ukrainą (wojna hybrydowa lub też wojna ,podprogowa”) Rosja dąży do zdestabilizowania sytuacji w południowej i wschodniej części Ukrainy, w celu ich oderwania bądź też doprowadzenia do sytuacji ,terenów okupowanych”, lub też do stworzenia quasi-państwa (casus Naddniestrza). Sytuacja ta rozgrywa się w bezpośrednim sąsiedztwie państw V4, a tym samym pośrednio wpływa na bezpieczeństwo państw Grupy Wyszehradzkiej. Działania prewencyjne na forum UE i OBWE są niezbędne dla stabilizacji sytuacji na Ukrainie (Stępniewski, 2016a, s. 337-344).

Szybki proces demokratycznych przemian na Ukrainie - w opinii rosyjskich polityków - stanowi ogromne zagrożenie dla interesów Rosji i jej decydentów politycznych. Jak wiadomo, demokratyzacja Ukrainy będzie możliwa dzięki pomocy struktur zachodnich i ścisłej z nimi współpracy. Rosja zdaje sobie z tego sprawę i dlatego tak ostro reaguje na możliwość członkostwa Ukrainy w UE i NATO. Można nawet zaryzykować stwierdzenie, że celem strategicznym Rosji wobec Ukrainy jest zapobiegnięcie jej demokratyzacji i integracji z Zachodem (szerzej zob. Stępniewski, 2016b, s. 181-193; Korosteleva, 2016b).

Znany i często komentujący w mediach zachodnich politykę międzynarodową rosyjski badacz Sergey Karaganov wielokrotnie powtarzał, że Rosja nie będzie potęga 
globalną, dopóki nie stanie się potęgą regionalną. Dlatego też zdaniem wielu badaczy Ukraina jest kluczowa dla projektów mocarstwowych Rosji (Szabaciuk, 2014, s. 75-86). Oczywiście Rosja mogłaby stać się potęgą regionalną, a w przyszłości odgrywać kluczową rolę w polityce światowej. Z jednej strony, wojna z Ukrainą stawia pod znakiem zapytania osiagnięcie tych celów przez Rosję. Z drugiej strony, aktywna polityka i działania zbrojne w Syrii powodują, że Rosja postrzegana jest jako ważny aktor w polityce bliskowschodniej, ale również w globalnym układzie sił.

Należy zauważyć, że na przestrzeni ostatnich dwóch dekad Rosja wykazała się olbrzymią determinacją $\mathrm{w}$ reintegracji obszaru poradzieckiego. Zagwarantowanie sobie hegemonicznych wpływów w przestrzeni poradzieckiej i wyparcie Zachodu służyć ma - w optyce Rosji - wzmocnieniu jej mocarstwowości w wymiarze regionalnym i globalnym oraz realizacji szeregu pomniejszych interesów o charakterze społecznoekonomicznym. Ponadto Rosja w celu obrony swojej strefy wpływów nie zawahała się przed obraniem konfrontacyjnej polityki wobec Zachodu. Należy też podkreślić, że zależność (na wielu płaszczyznach) Ukrainy i innych państw PW od Rosji jest znaczna i wyraźna. Innymi słowy, Rosja posiada wiele instrumentów wpływu na sytuację wewnętrzną tych państw (Stępniewski, 2016a, s. 337-344; Korosteleva, 2013, s. 11-36).

\section{Polska i inne państwa Grupy Wyszehradzkiej wobec państw Europy Wschodniej i Kaukazu Południowego}

Dla państw Grupy Wyszehradzkiej (także: V4) w Europie Wschodniej Ukraina jawi się jako najważniejsze państwo z racji swojej wielkości terytorialnej, potencjału demograficznego oraz posiadania wspólnej granicy z trzema członkami wyszehradzkimi - Polską, Słowacją i Węgrami. Tym samym uwarunkowania geopolityczne wpływają na preferencje w polityce zagranicznej państw V4. Ale nie tylko kwestie geopolityczne mają znaczenie w odniesieniu do kierunków działania V4, lecz również chęć stworzenia stabilnego, bezpiecznego, demokratycznego i integrującego się z Unią Europejską wschodniego sąsiedztwa (Stępniewski, 2015b, s. 29-31). Polska, jak również pozostałe państwa V4 wyrażają chęć posiadania Zachodu na Wschodzie, czyli demokratycznych i stabilnych państw (jak ma to miejsce w Europie Zachodniej) na wschodzie Europy. Im bardziej stabilne i bezpieczne wschodnie sąsiedztwo państw V4 (szerzej UE), tym pewniejsza sytuacja państw wyszehradzkich, szerzej całej Unii Europejskiej (Stępniewski, 2012, s. 159-173).

Największym problemem w europeizacji państw Partnerstwa Wschodniego jest jednak brak poparcia ze strony największych państw UE dla ich przyszłego członkostwa w Unii Europejskiej. Jest to sytuacja błędnego koła. Państwa PW potrzebują perspektywy członkostwa w celu intensyfikacji reform, z drugiej strony niewielkie reformy lub ich brak powodują, że państwa UE nie wyrażają zgody na przyznanie im perspektywy członkostwa (Balcer, 2013, s. 90). Dla wzmocnienia interesów Polski na wschodzie - jak podkreśla Przemysław Żurawski vel Grajewski - ważne jest, żeby nastapiło w drodze ,politycznego przesunięcia Ukrainy, Białorusi, Gruzji, Azerbejdżanu, Mołdawii i Armenii (w tym właśnie porządku, odzwierciedlającym wagę znaczenia poszczególnych państw dla interesów bezpieczeństwa Polski) na Zachód - czyli 
ich okcydentalizacji, rozumianej jako przyjęcie przez te kraje zachodnioeuropejskich wzorów ustrojowych i obranie przez nie orientacji na integrację europejską i euroatlantycką, a nie na Rosjęe" (Żurawski vel Grajewski, 2010, s. 38). Warunkiem uzyskania perspektywy integracji europejskiej przez państwa PW jest poprawa jakości demokracji i sytuacji ekonomicznej, gdyż obecnie kwestie rozszerzenia UE na Wschód są swego rodzaju science fiction (Balcer, 2013, s. 95).

O ile Polska, która jako największe państwo V4 w UE ma wiele do osiągnięcia, silnie angażuje się w projekt Partnerstwa Wschodniego jako główną idée fixe Grupy, o tyle stanowisko pozostałych państw pozostaje dużo mniej jednoznaczne i entuzjastyczne. Czechy, na przykład, wydają się optować za Grupą jako blokiem mniej zobowiązującym politycznie, zaś Słowacja jako państwo o rachitycznej i nietrwałej proeuropejskiej kulturze politycznej pozostaje oponentem nazbyt ambitnej ponadregionalnej aktywności V4. Z kolei Węgry postrzegają aktywność Grupy przez pryzmat tzw. korzyści komparatywnych, ograniczają jej funkcjonowanie do wymiaru pragmatycznego, to jest związanego przede wszystkim z procesem absorpcji kapitału zagranicznego, mającego fundamentalne znaczenie dla rozwoju ekonomicznego regionu Europy Środkowo-Wschodniej (Kobzová, 2012, s. 62-63).

Zaangażowanie państw Grupy Wyszehradzkiej w projekt Partnerstwa Wschodniego (szerzej polityki wschodniej Unii Europejskiej) jest istotne - zdaniem Krzysztofa Szczerskiego - z trzech co najmniej powodów. Po pierwsze, ten wymiar działań Unii Europejskiej może stać się swego rodzaju „dźwignią podmiotowości” V4 w polityce Wspólnoty. Po drugie, polityka wschodnia UE i w jej ramach Partnerstwo Wschodnie są ważne $\mathrm{z}$ punktu widzenia instytucjonalnego układu w systemie politycznym Wspólnoty (chodziło wówczas, 2010 rok, o układ personalny: zajmowanie wysokich stanowisk w instytucjach UE przez przedstawicieli V4 oraz o sprawowanie prezydencji przez państwa wyszehradzkie w Radzie Unii Europejskiej przez cały 2011 rok - najpierw Węgry, później Polska). Po trzecie, ten wymiar i instrument polityki są niezwykle ważne jako swoisty test na strategiczny wymiar V4. Popieranie projektu Partnerstwa Wschodniego przez wszystkie państwa V4 będzie potwierdzeniem dojrzałości politycznej państw wyszehradzkich oraz zdolności do tworzenia ofensywnych i konstruktywnych stanowisk w polityce europejskiej (Szczerski, 2010, s. 52-54). Tym samym V4 nie będzie jedynie „koalicją państw niewypłacalnych”, które jednoczą się tylko w kwestii blokowania kosztownych projektów (np. polityki klimatycznej - limity w emisji dwutlenku węgla) lub innych niewygodnych dla V4 rozwiązań, które są proponowane przez najbogatsze państwa Unii.

Z punktu widzenia polityki wschodniej Unii Europejskiej słabością państw V4 jest brak obecności Grupy we wszystkich państwach PW, jednak z drugiej strony pojedyncze państwa Grupy Wyszehradzkiej przeważnie mają dość mocną pozycję w poszczególnych państwach PW, choć nie w kilku jednocześnie (Balcer, 2013, s. 91). Co ważne, stosunki gospodarcze V4 z państwami Kaukazu Południowego nie układają się najlepiej. Warto przypomnieć, że im większe zaangażowanie gospodarcze i społeczne państw V4 w regionie PW, tym mniejsza obecność Rosji, a tym samym proces demokratyzacji może okazać się łatwiejszy. Wzrost zaangażowania biznesu europejskiego w państwach PW zwiększa szanse na zmianę zasad gry na Wschodzie (Balcer, 2013, s. 92). Zmiana owych zasad gry może wynikać nie tylko z obecności gospodarczej V4 
i UE, ale również z pomocy udzielanej społeczeństwu obywatelskiemu, programów stypendialnych dla studentów państw PW na terytorium Unii Europejskiej.

Z jednej strony, wojna Rosji z Ukrainą ujawnia coraz większe różnice stanowisk państw V4 wobec tego konfliktu. Jest to widoczne zwłaszcza przy okazji dyskusji o sankcjach nakładanych przez Unię Europejską na Rosję w związku z jej działaniami wobec Ukrainy. Okazuje się, że nie tylko Węgry są sceptycznie nastawione do wprowadzonych sankcji, ale także Czechy i Słowacja. Polska jawi się tu jako państwo osamotnione w walce o sprawy Ukrainy. Sytuacja ta pokazuje, że należy postawić pytania o spójność działań V4 i możliwość realizacji wspólnych projektów, a także o dzisiejszą kondycję Grupy Wyszehradzkiej. Z drugiej strony, Grupa Wyszehradzka nie jest i nie była monolitem i podziały oraz różnice stanowisk nie są niczym nowym. $\mathrm{O}$ wiele więcej można osiagnąć, jeśli wyjdziemy z założenia, że Grupa Wyszehradzka jest platformą współpracy, niż jeśli będziemy się zastanawiać, jakie należy podjąć działania, żeby zmienić sytuację.

Jak wskazano powyżej, państwa Grupy Wyszehradzkiej jako aktywni członkowie Unii Europejskiej, a także NATO, starają się działać na rzecz integracji euroatlantyckiej państw PW. Przykładem takiego zaangażowania państw V4 jest właśnie projekt Partnerstwa Wschodniego.

\section{Konkluzje}

Z jednej strony, polityka Partnerstwa Wschodniego Unii Europejskiej jest projektem długoterminowym i w takich kategoriach powinna być on postrzegana. $Z$ drugiej strony, należy również pamiętać, że wśród państw członkowskich Unii Europejskiej - jak zauważa Krzysztof Szczerski - występują państwa przeciwne, obojętne lub sojusznicze wobec polityki wschodniej Unii Europejskiej, w tym wobec inicjatywy Partnerstwa Wschodniego. Do pierwszej kategorii (przeciwników) zaliczają się państwa, które między innymi zainteresowane są innymi kierunkami geograficznego oddziaływania UE czy też priorytetem są dla nich stosunki UE-Rosja w polityce wschodniej Wspólnoty. Druga kategoria (obojętne) to państwa, które nie mają własnych preferencji geopolitycznych - są zbyt słabe i małe, albo nie widzą przeszkód w wypracowaniu nowego kierunku w polityce zewnętrznej UE. Do trzeciej kategorii (sojusznicy) należą państwa, które uważają, że wariant polityki wschodniej określanej przez PW w większym lub mniejszym stopniu realizuje także ich interesy. Do grupy tej możemy zaliczyć trzy państwa Grupy Wyszehradzkiej: Polskę, Republikę Czeską i Węgry, ale również np. Szwecję (Szczerski, 2010, s. 55). Należy podkreślić fakt, że o sukcesie polityki wschodniej Unii Europejskiej nie zadecydują jedynie państwa członkowskie Wspólnoty, ale również państwa, do których ta polityka jest adresowana - czyli państwa Europy Wschodniej i Kaukazu Południowego.

W tytule artykułu jest mowa o podejściu Unii Europejskiej do kwestii niestabilnego wschodniego sąsiedztwa. W związku z tym rodzi się pytanie o skuteczność tej polityki, jej kształt i wyzwania. W 2017 roku mija osiem lat od uruchomienia projektu PW i potrzebne jest ponowne spojrzenie na ten projekt, jego osiagnięcia, cele i możliwości. Inaczej mówiąc, należy podjąć działania na rzecz realizacji projektu Partnerstwa 
Wschodniego 2.0. Tym bardziej potrzebny jest taki przegląd z nim związany, gdyż w 2017 roku planowany jest szczyt PW w Brukseli. Konieczna jest zmiana podejścia, ale również narracji, jeśli chodzi o projekt PW i państwa nim objęte. W polityce ważne są między innymi symbole, a takim symbolem będzie szczyt PW w 2017 roku, a także nowa odsłona tej polityki (Stępniewski, 2016, s. 337-344). Należy wskazać na nowe obszary i płaszczyzny, w których PW będzie stwarzało możliwość zacieśniania współpracy między PW a UE. Tym samym będzie można podkreślić, że głosy ekspertów i polityków z państw PW o tym, że projekt ten upadł, są niesłuszne i niezgodne ze stanem faktycznym. Nie można jednak zapominać, że w UE mamy do czynienia z sytuacją, w której myślenie o państwach PW schodzi na dalszy plan. Dlatego też ważne jest, żeby państwa Grupy Wyszehradzkiej na forum UE przypominały o sytuacji państw PW, wstawiały się za nimi, żeby nie pozwalały zapomnieć o toczącej się wojnie Rosji z Ukrainą na Donbasie. Kryzys Ukrainy jest wyzwaniem nie tylko dla bezpieczeństwa Ukrainy, ale też dla bezpieczeństwa i porządku europejskiego i światowego. Jak zauważa Paul Ivan, istotne jest dla UE podkreślanie, że to Rosja dokonała aneksji Krymu, to Rosja prowadzi wojnę z Ukrainą i to Rosja złamała zasady prawa międzynarodowego (Wywiad z Paulem Ivanem, 2016). Sankcje nałożone przez UE na Rosję są właściwą reakcją na politykę faktów dokonanych prowadzoną przez Rosję. Dlatego UE powinna naciskać na realizację porozumień Mińsk II i ich implementację przez Rosję.

Rekapitulując, podejście UE do państw PW musi ulec zmianie, gdyż zmieniła się sytuacja geopolityczna we wschodnim sąsiedztwie. Konflikt zbrojny na Ukrainie i tym samym niestabilność wschodniego sąsiedztwa stanowią wyzwanie dla bezpieczeństwa całego obszaru Europy Wschodniej. Dodatkowo, coraz bardziej asertywna postawa Rosji wobec wschodnich sąsiadów powoduje, że UE zmuszona jest do reagowania. Zdaniem Richarda Youngsa, konflikt zbrojny na Donbasie powoduje, że UE zmieniła swe podejście do wschodnich sąsiadów. Określa on nowe podejście mianem geopolityki hybrydowej lub liberalno-redukcyjnej (ang. ,,a hybrid or liberal-redux geopolitics") (Youngs, 2017). Dodatkowo, nowy prezydent USA Donald Trump również nie wykazuje zbytniej wrażliwości w kwestii spraw Europy Wschodniej (szczególnie Ukrainy), co też kształtuje nowe warunki do rozwiązywania spraw wschodnich.

Analizując politykę Partnerstwa Wschodniego, należy zaznaczyć dwie bardzo ważne kwestie. Pierwsza kwestia związana jest z tym, że nie wszystkie państwa PW są skłonne do zacieśniania współpracy. W związku z tym pojawia się pytanie: $\mathrm{w}$ jaki sposób UE może skutecznie współdziałać z państwami PW, skoro część z nich nie wyraża takiego zainteresowania? W jaki sposób polityka UE może być skuteczna, skoro brakuje wzajemnej współpracy i zrozumienia? Należy również pamiętać, że jednym $\mathrm{z}$ istotnych elementów utrudniających współpracę UE z państwami PW jest korupcja, która trawi systemy polityczne państw PW oraz w znacznym stopniu uniemożliwia zmianę sytuacji tych państw. Drugą kwestią jest samo podejście UE do wschodniego sąsiedztwa, brak sprawnego działania i reagowania na sytuację na tym obszarze oraz przekształcanie projektu Partnerstwa Wschodniego w technokratyczny, biurokratyczny mechanizm. Jak słusznie zauważa Adam Eberhardt, PW było projektem, który niegdyś inspirował Ukraińców, Mołdawian i Gruzinów do działania i rodził nadzieje na zmiany w tych państwach, natomiast obecnie staje się coraz bardziej symbolem biu- 
rokratycznej bezradności w dobie konfrontacji geopolitycznej i społecznej turbulencji (Eberhardt, 2017).

\section{Bibliografia}

Ash T.-G. (2017), Chaos, zamęt i smutna królowa. W pierwsza rocznice Brexitu, „Gazeta Wyborcza”, 22 czerwca, http://wyborcza.pl/7,75968,21996813, chaos-zamet-i-smutna-krolowa-wpierwsza-rocznice-brexitu.html, 19.07.2017.

Balcer A. (2013), Ostatni dzwonek dla Partnerstwa Wschodniego, „Nowa Europa Wschodnia”, nr 3-4 (XXIX-XXX), maj-sierpien.

Barburska O., Milczarek D. (2014), Polityka wschodnia Unii Europejskiej. Porażka czy sukces?, Oficyna Wydawnicza Aspra-JR, Warszawa.

Besier G., Stokłosa K. (red.) (2017), Neighbourhood Perceptions of the Ukraine Crisis. From the Soviet Union into Eurasia?, Routledge, Oxon-New York.

Bouris D., Schumacher T. (red.) (2016), The Revised European Neighbourhood Policy: Continuity and Change in EU Foreign Policy, Palgrave Macmillan, Basingstoke.

Delcour L., Wolczuk K. (2015), Spoiler or Facilitator of Democratization? Russia's Role in Georgia and Ukraine, „Democratization”, vol. 22.

Eberhardt A. (2017), The Semblance of Partnership. On the Eastern Policy of the European Union, „Polski Przegląd Dyplomatyczny”, http://www.ppd.pism.p1/Numery/3-70-2017/The-Semblance-of-Partnership-Adam-Eberhardt, 19.07.2017.

Fiszer J. -M. (2014), System transatlantycki w multipolarnym ładzie międzynarodowym: szanse i zagrożenia, w: Wspótpraca transatlantycka. Aspekty polityczne, ekonomiczne i społeczne, red. J. Fiszer, P. Olszewski, B. Piskorska, A. Podraza, Instytut Studiów Politycznych PAN, Fundacja Konrada Adenauera, Warszawa.

Góralczyk B. (2014), Unia Europejska jako aktor na scenie globalnej. Razem czy osobno?, Centrum Europejskie Uniwersytetu Warszawskiego, Warszawa.

Góralczyk B.-J. (2014), The Crisis of 2008 and 2014 and the New Role of the European Union on the Global Scene, w: European Union on the Global Scene: United or Irrelevant?, red. B. J. Góralczyk, Centre of Europe, Warsaw.

Harasimowicz A. (2016), Europejska polityka sqsiedztwa - pechowa pierwsza dekada, „Studia Europejskie", nr 2, ss. 29-34.

Haukkala H. (2015), From Cooperative to Contested Europe? The Conflict in Ukraine as a Culmination of a Long-Term Crisis in EU-Russia Relations, „Journal of Contemporary European Studies", vol. 23, nr 1

Judah T. (2015), In Wartime: Stories from Ukraine, Penguin, London.

Kaczorowska M. (2016), Krajobraz polityczny po Brexicie, „Sprawy Międzynarodowe”, rok LXIX, nr 3.

Kobzová J. (2012), The Visegrad Group in Eastern Europe: an actor, not a leader yet, „Visegrad Insight", $\mathrm{nr} 2$.

Korosteleva E. (2013), Evaluating the role of partnership in the European Neighbourhood Policy: The Eastern neighbourhood, „Eastern Journal of European Studies”, vol. 4, nr 3.

Korosteleva E. (2016a), The European Union, Russia and the Eastern region: The analytics of government for sustainable cohabitation, „Cooperation and Conflict”, vol. 51, $\mathrm{nr} 3$.

Korosteleva E. (2016b), EU-Russia relations in the context of the eastern neighbourhood, „Policy Brief", Bertelsmann Stiftung, May, Gütersloh. 
Kostanyan H. (red.) (2017), Assessing European Neighbourhood Policy. Perspectives from the literature, CEPS, Rowman and Littlefield International, Brussels-London.

Kuźniar R. (2016), Europa w porzadku międzynarodowym, Polski Instytut Spraw Międzynarodowych, Warszawa.

Lannon E. (2015), More for more or less for less: From the rhetoric to the implementation of European Neighbourhood Instrument in the Context of the 2015 ENP review, „IEMed Overview”, European Institute of the Mediterranean, Barcelona.

Larrabee F. S., Wilson P. A., Gordon IV J. (2015), The Ukrainian Crisis and European security: Implications for the United States and U.S. Army, RAND Corporation, Santa Monica, CA.

Natorski M. (2016), The EU and crisis in Ukraine: Policy continuity in times of disorder?, w: The Revised European Neighbourhood Policy: Continuity and Change in EU Foreign Policy, red. D. Bouris, T. Schumacher, Palgrave Macmillan, Basingstoke.

Popowski M. (2016), Deputy Director-General for Neighbourhood and Enlargement Negotiations (DG NEAR), European Commission, w czasie dyskusji panelowej pt. „Money in Politics: State-building, democracy and corruption in the Eastern Neighbourhood", European Endowment for Democracy and the Office of International IDEA, Brussels, 16 września 2016.

Rácz A. (2012), The Greatest Common Divisor: Russia’s Role in Visegrad Foreign Policies, „The Polish Quarterly of International Affairs", vol. 21, nr 4, Autumn.

Rieker P. (2014), The European Neighbourhood Policy: An instrument for security community building, NUPI Working Paper, no. 832, Norwegian Institute of International Affairs, Oslo.

„Rocznik Instytutu Europy Środkowo-Wschodniej” (2014), red. T. Stępniewski, A. Gil, A. Szabaciuk, A. Visvizi, rok 12, zeszyt 2, pt. Majdan 2014: Ukraina na rozdrożu, Lublin.

Sakwa R. (2016), Frontline Ukraine: Crisis in the Borderlands, I. B. Tauris, London.

Shekhovtsov A., Umland A. (2014), Ukraine's Radical Right, „Journal of Democracy”, vol. 25, $\mathrm{nr} 3$.

Stępniewski T. (2011), Geopolityka regionu Morza Czarnego w pozimnowojennym świecie, Instytut Europy Środkowo-Wschodniej, Lublin-Warszawa.

Stępniewski T. (2012), Działania Unii Europejskiej wobec konfliktów na Kaukazie Południowym, w: Europejska Polityka Sąiedztwa Unii Europejskiej, red. M. Pietraś, K. Stachurska-Szczesiak, J. Misiagiewicz, Wydawnictwo UMCS, Lublin.

Stępniewski T. (2015), Unia Europejska, Ukraina i Rosja: kryzysy i bezpieczeństwo, „Studia Europejskie", Centrum Europejskie Uniwersytetu Warszawskiego, nr 4 (76), Warszawa.

Stępniewski T. (2015b), ENP or ENPs? The curious web of the European Neighbourhood Policy: the Southern and Eastern Dimensions revisited, „Rocznik Instytutu Europy ŚrodkowoWschodniej", red. A. Visvizi, T. Stępniewski, rok 13, zeszyt 4, pt. European Neighbourhood Policy after the Arab Spring and Russia-Ukraine hybrid war.

Stępniewski T. (2016a), The European Union and Eastern Partnership: Crises and Strategic Assessment, „Rocznik Instytutu Europy Środkowo-Wschodniej”, red. B. Jóźwik, T. Stępniewski, rok 14, zeszyt 5, pt. Transformacja, integracja i kryzysy w Europie Środkowej i Wschodniej.

Stępniewski T. (2016b), The Eastern Policy of the European Union. The Role of Poland, „POLITEJA. Pismo Wydziału Studiów Międzynarodowych i Politycznych Uniwersytetu Jagiellońskiego", nr 41.

Szabaciuk A. (2014), Eurazjatycki projekt integracyjny Władimira Putina: szanse i zagrożenia, „Rocznik Instytutu Europy Srodkowo-Wschodniej”, red. T. Stępniewski, A. Gil, A. Szabaciuk, A. Visvizi, rok 12, zeszyt 5, pt. Rosja Putina - Ukraina - Europa: geopolityka, bezpieczeństwo, gospodarka, Lublin.

Szczerski K. (2010), Polityka wschodnia Unii Europejskiej a strategia Grupy Wyszehradzkiej, w: Partnerstwo Wschodnie w kontekście Europejskiej Polityki Sasiedztwa i agendy Grupy Wyszehradzkiej, red. I. Albrycht, Instytut Kościuszki, Kraków-Bruxelles. 
The World Bank (2016), Ukraine Economic Update, September 22, http://pubdocs.worldbank.org/ en/705541474523591719/WB-Economic-Update-September-2016-en.pdf, 19.07.2017.

Thompson J. (2015), The Global Players in the EU's Broader Neighbourhood, w: The neighbours of the European Union's neighbours: Diplomatic and geopolitical dimensions beyond the European neighbourhood policy, red. S. Gstöhl, E. Lannon, $1^{\text {st }}$ edition, Ashgate Publishing Ltd., Farnham.

Wilson A. (2014), Ukraine Crisis: What It Means for the West, Yale University Press, New Haven, CT.

Youngs R. (2017), Is "Hybrid Geopolitics” the Next EU Foreign Policy Doctrine?, „Carnegie Europe", 19 June 2017, http://carnegieeurope.eu.

Youngs R. (2017), Europe's Eastern Crisis. The Geopolitics of Asymmetry, University Press, Cambridge.

Żakowski J. (2016), Ogniska choroby. Politolog Jan Zielonka o globalnym kryzysie demokracji, „Polityka”, 1.01-12.01, nr 1/2 (3041).

Żurawski vel Grajewski P. (2010), Partnerstwo Wschodnie Unii Europejskiej - główne czy pomocnicze narzędzie polskiej polityki wschodniej?, w: Partnerstwo Wschodnie w kontekśsie Europejskiej Polityki Sasiedztwa i agendy Grupy Wyszehradzkiej, red. I. Albrycht, Instytut Kościuszki, Kraków-Bruxelles.

\section{Wywiady:}

Wywiad 1, European External Action Service (EEAS), Headquarters Brussels; Russia Division, 15 września 2016.

Wywiad 2, European External Action Service (EEAS), Headquarters Brussels; Eastern Partnership, regional cooperation and OSCE, 15 września 2016.

Wywiad z Paulem Ivanem (European Policy Centre, Brussels), 12 września 2016.

\section{Streszczenie}

Niniejszy artykuł - w sposób bardzo skrótowy - analizuje politykę Unii Europejskiej wobec wschodnich sąsiadów. W pierwszej kolejności ukazano sytuację UE (kryzysy, z jakimi boryka się Wspólnota), a następnie zaprezentowano sytuację państw wschodniego sąsiedztwa (przez pryzmat polityki Partnerstwa Wschodniego), z położeniem nacisku na tzw. kryzys ukraiński. Kryzys ukraiński, de facto trwający konflikt zbrojny Rosji z Ukraina, powoduje, że zmianie uległa nie tylko sytuacja geopolityczna Europy Wschodniej, ale również warunki, w jakich realizowana jest polityka wschodnia Unii Europejskiej. Inaczej mówiąc, agresja Rosji na Ukrainę spowodowała, że UE znalazła się w bardzo trudnej sytuacji i zmuszona została do zmiany swej polityki względem Rosji.

Projekt Partnerstwa Wschodniego Unii Europejskiej jest projektem długoterminowym i w takich kategoriach powinien być postrzegany. Należy również pamiętać, że wśród państw członkowskich Unii Europejskiej występują państwa przeciwne, obojętne lub sojusznicze w odniesieniu do polityki wschodniej Unii Europejskiej, w tym do inicjatywy Partnerstwa Wschodniego.

Słowa kluczowe: Unia Europejska, Europa Wschodnia, Partnerstwo Wschodnie, Ukraina, kryzys ukraiński 


\section{Looking out to the East: European Union vs. unstable eastern neighborhood}

\section{Summary}

The present paper constitutes a brief analysis of the EU's policy towards its eastern neighbors. The paper outlines the condition of the EU (crises the Union is struggling with). Next, the situation of countries in the eastern neighborhood was presented in light of the Eastern Partnership policy. Particular emphasis was placed upon the Ukrainian crisis. The crisis, a de facto, armed conflict between Russia and Ukraine, has resulted not only in a geopolitical change in Eastern Europe, but also exerted impact upon conditions the EU's eastern policy is realized in. In other words, Russia's aggression on Ukraine placed the EU in a precarious position forcing the Union to change its policy towards Russia.

The Eastern Partnership project constitutes a long-term policy, and ought to be perceived as such. The fact that within the EU itself there exist forces which are against, neutral, and supporting of the EU's eastern policy, including the Eastern Partnership, is noteworthy.

Key words: European Union, Eastern Europe, Eastern Partnership, Ukraine, Ukraine's Crisis 
